Article

\title{
Impact of Climate Change on the Argan Biosphere Reserve
} $(\mathrm{ABR})$ in Morocco

\author{
Hamza El Ghazali ${ }^{1}$, Salma Daoud ${ }^{2}$, Noureddine Benoada Tlemçani ${ }^{1}$ and CherifHarrouni ${ }^{1}$ *
}

\footnotetext{
1 Department of Landscape Architecture \& Environment, Hassan $2^{\text {nd }}$ Institute of Agronomy and Veterinary Medicine, Agadir and Rabat, Morocco

2 Department of Biology, Ibn Zohr university, Agadir, Morocco

* Corresponding author: c.harrouni@iav.ac.ma
}

\begin{abstract}
This paper explores the effect of climate change on the regression of the Argan tree (Argania spinosa L. Skeels) woodland, focusing on the Argan Biosphere Reserve and especially in the Souss plain (Western Morocco). Rainfall and temperature data of four sites within the Argan Biosphere Reserve were analyzed over the last 60 years to assess any climatic change. Regression curves applied to the dataset showed an important decrease in rainfall (18 to $26 \%$ ) in the four locations as well as an increase in temperature $\left(1\right.$ to $\left.2{ }^{\circ} \mathrm{C}\right)$. These changes may have a detrimental effect on the Argan woodland although human factors have been reported to be the main factor of its regression. It can therefore be concluded that the reduction in rainfall and the increase in temperature should now be considered as factors of Argan woodland regression.
\end{abstract}

Keywords: Argan biosphere reserve, Climate change, Rainfall, Temperature, Woodland regression

\section{Introduction}

The Argan Biosphere Reserve (ABR) is located in Western Morocco on the Atlantic coast. This is a peculiar woodland considered as a natural barrier against desertification in an arid bioclimatic context [1]. The Argan tree is a forest species that constitutes an important ecosystem due to its eco-geographical and socio-economic dimensions. The Argan woodland covers over 800,000 hectares representing Morocco's second largest forest after the ilex (Quercus rotundifolia) [2]. The ABR is an area stretching from Essaouira in the north to Sidi Ifni in the south along the Atlantic coast and eastwards at the connexion between the High and the Anti-Atlas Mountains. It occupies an area of nearly $25,000 \mathrm{~km}^{2}$, comprising other forest species in addition to the Argan [1]. The population is about 3 million inhabitants depending on the direct exploitation of the Argan tree for almost half the population (1.3 million people) $[2,3]$.

During the $20^{\text {th }}$ century, the Argan woodland experienced significant degradation, decreasing its density from 300 trees/ha at the turn of the century to less than 100 trees/ha in the 1990s, a loss of 2/3 of the natural heritage [4]. This degradation is mainly due to anthropogenic factors including overgrazing, logging for domestic wood, intensive agriculture and urbanization. Climatic factors related to global warming may have exacerbated the situation.

This paper focuses on the analysis of climatic data to reveal any changes on a 60 years historical scale and envisage its contribution to the regression of Argan woodland. A study conducted over a 20 -years period by diachronic analyses of aerial photographs showed a 
decline of $c a 600$ ha/year for the Admin forest that spans on 22,000 ha in the Souss plain close to Agadir [4].

The recognition of the Argan woodland as a Biosphere Reserve was pronounced by UNESCO in December 1998 and underwent 2 decennial reports in 2008 and 2018 with specific recommendations for each report [5]. The ABR is a unique hotspot of global biodiversity. Yet this natural heritage continues to be under threat due to anthropogenic pressure, recently accentuated by the effects of climate change [4].

\section{Natural environment}

The Argan tree is endemic to Morocco representing the linchpin of a traditional agrarian system that has so far been able to meet the needs of a dense population in an area facing economic, social and environmental challenges [6]. This tree is particularly suitable for the region thanks to its deep root system and its great resistance to heat (up to $50^{\circ} \mathrm{C}$ in summer) [6]. The Argan tree is considered to be the last survivor of the tropical sapotaceae family, a species that spread to Morocco during the tertiary geological era in a warm and more humid climate, thus constituting a relic tree [7]. The Argan woodland covers a vast intramountain plain with its mountainous borders, the whole being variably open to the west on the Atlantic Ocean [6]. The maximum altitude above sea level where the Argan can be found is about $1,500 \mathrm{~m}$ and the minimum altitude is that of sea level on the coastline.

According to Peltier's work [7], the Argan woodland spans several bioclimatic storeys: from cool semi-arid areas of the south (Souss plain) to sub-humid areas in the High Atlas Mountain [7]. This woodland is inhabited by a population estimated at more than 3 million people. This population has tripled in the last fifty years and has become highly urbanized (50\% urban in 2009) [3,6].

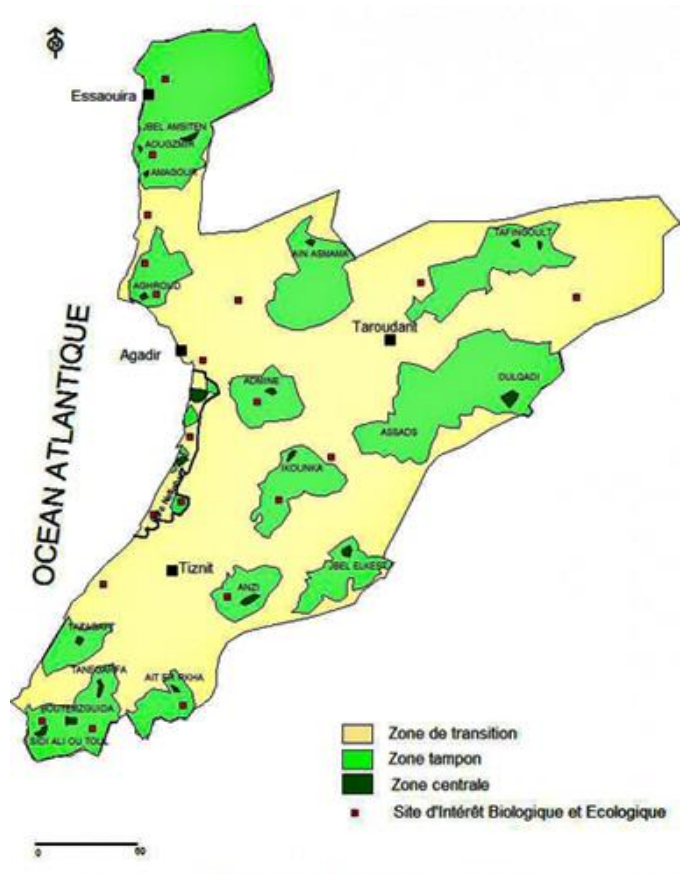

(a)

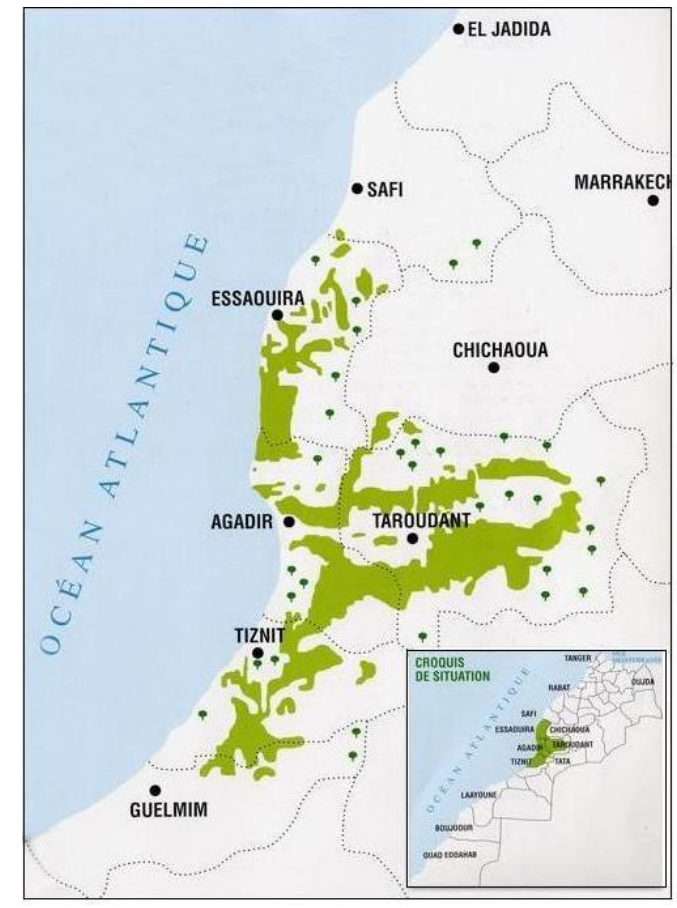

(b)

Figure 1. (a) Location of the Argan Biosphere Reserve and its 3 zones (core, buffer and transition (b) Argan tree cover and location of cities for climate data study (Agadir, Essaouira, Taroudant and Tiznit) [30]. 


\section{Hydrology and water consumption}

\subsection{Hydrology and water consumption}

\subsubsection{Groundwater}

In Morocco, groundwater resources are overexploited [9]. According to estimates made in 2011 by the Souss-Massa Hydraulic Basin Agency, the deficits in groundwater resources in the Souss plain have reached $300 \mathrm{Mm}^{3}$. The Souss-Massa basin contains one of the largest aquifers in the country [9]. The development of Agriculture, industry and tourism in this area since 1930, on the one hand, and the irregularity of rainfall for surface water resources, on the other, have led to the overexploitation of groundwater whose levels are steadily declining [10]. In addition to the depletion of this resource, the cost of its mobilization continues to increase due to the pumping energy cost related to the increase in depth. The Souss plain aquifer is a renewable underground system closely dependent on the local climate and hydro geological regimes [10]. Its overall volume is about 40 billion $\mathrm{m}^{3}$ but its annual average recharge is estimated at about $400 \mathrm{Mm}^{3}$ or $1 / 5$ of the overall regional hydraulic potential and $2 / 3$ of the regional underground hydraulic potential [11]. The water table of the Souss plain is mainly supplied from runoff and especially from floodwaters of the relatively dense water system and locally from direct rainfall. Feeding from groundwater adjacent to the mountains or from deep aquifers is quite limited due to unsuitable geological conditions and the aridity of the Anti-Atlas Mountains. On the other hand, natural water outflows of this water resource are represented by evaporation that intensifies in summer, the series of springs along the bed of the Souss River currently dry, and by a part of the water that finds its way to the ocean [11].

The water balance of the Souss aquifer is irregular because of the high climate variability, but in recent decades, this balance has become continuously negative due to the overexploitation of underground water. The deficit is mainly due to water pumping for irrigation purposes [11].

\subsubsection{Surface water}

The entire Argan woodland is characterized by a shallow water regime that is far from regular. It is subject to the aggressiveness of the rain that occurs after long periods of drought [12]. Floods are closely related to localized thunderstorms that can occur even in dry valleys [11]. The opening of the Souss plain on the ocean ensures the moisture necessary for the development of the Argan tree and the most beautiful Argan formations (by their density, canopy and height) are located on the coast between Agadir and Essaouira [12]. In the High Atlas Mountains, the amount of rain is much greater (between 200 and $900 \mathrm{~mm} /$ year) [13]. Snow from the peaks plays an important role in feeding the water table and regulates water supply by prolonging the period of runoff. The Souss River supplies most of the available water of the basin [13]. In total, available water in the basin is about $1,100 \mathrm{Mm}^{3}$ of which $61 \%$ is surface water and the remaining is groundwater [14]. Surface water is collected and stored in reservoirs of seven dams that have a combined total capacity of approximately $800 \mathrm{Mm}^{3}[14]$.

Table 1. Average annual water potential stored in Souss-Massa dams 


\begin{tabular}{cccc}
\hline Dam & River & In-service date & Water storage capacity $\mathbf{( M m}^{\mathbf{3}} \mathbf{~}$ \\
\hline Ibn Tachffine & Massa & 1973 & 303.5 \\
\hline Abdel Moumen & Issen & 1981 & 214 \\
\hline Aoulouz & Souss & 1991 & 108 \\
\hline Imi Lkheng & Talekjount & 1993 & 11 \\
\hline Moulay Abdellah & Tamri & 2003 & 110 \\
\hline Ahl Souss & Ait Baha & 2004 & 2.2 \\
\hline Mokhtar soussi & Aouziwa & 2012 & 50 \\
\hline
\end{tabular}

Data communicated by the Souss Massa Hydraulic Basin Agency (SMHBA), Agadir.

\subsection{Water use}

Various uses and activities impact water resources in terms of quantity and quality. Population, urban development, land use, industrialization, deforestation, etc are the main factors affecting water resources [15]. In the Argan area, agricultural land covers over 160,000 ha of which nearly $50 \%$ are irrigated, the other half being rain-fed [16]. Cereals, citrus, bananas, tomatoes and other vegetables are the main crops cultivated in the Souss plain [16]. About $80 \%$ of farms are smaller than 5 ha (covering $80 \%$ of cultivated land) and only $2 \%$ are bigger than 20 ha [16]. With a year-round growing season, irrigated crop production produces more than half of Morocco's exported citrus and 85\% of exported vegetables [16]. Irrigation is therefore the main use of available water as it takes up to 95\% although the demand for drinking water will increase due to more accelerated urbanization [16]. The monthly use of irrigation water in the Souss plain mainly consists of surface water supplies mounting to over $159,000 \mathrm{Mm}^{3}$ (28.6\% of total irrigation water) and of water pumping from the aquifer estimated at 397,000 $\mathrm{Mm}^{3}(71.4 \%)$ [17].

\section{Human activities and land management}

The Argan Biosphere Reserve continues to be under threat due to anthropogenic pressure. In fact, $80 \%$ of this important ecosystem is located in the Souss-Massa basin. This region is actually one of the most dynamic regions in Morocco [3]. It is constituted of two complementary geographical units: the Souss and the Massa basins that represent the country's leading horticultural and tourist region [16]. They ensure the Moroccan agricultural exports and cover more than ten months of the food requirements of the country. They therefore play very important socio-economic and environmental roles [17].

As stated earlier, the region hosts 3 million inhabitants of which two-thirds live in the Argan biosphere reserve [18]. According to official statistics from the Office of the High Commissioner for Planning (2019), the regional economy is based on four key economic sectors that drain 79 billion dirhams (over 8 billion USD), as a gross domestic product: tourism, which accounts for $5.7 \%$ of income, agriculture $14.4 \%$, industry $8 \%$ and fisheries $4 \%$.

The Argan Biosphere Reserve has multiple roles that can be summarized as follows:

1. Economic role: The "Argan" ecosystem is intimately linked to the daily life of the people of the region through the services it provides [18]. Fruit production (Argan nuts) varies according to age and density (20 to $100 \mathrm{~kg} /$ tree) with an average of $40 \mathrm{~kg} /$ tree/year [19]. Based on the average density of the Argan stands (approximately 50 trees per hectare) and the yield of Argan oil (3 litres per $100 \mathrm{~kg}$ of dry nuts), the potential production is estimated at 32,000 tons of Argan oil 
per year [19]. The average pastoral production of the Argan woodland is estimated at 200 fodder units/ha/year, or nearly 174 million fodder units, equivalent to 174,000 metric tons of barley. This production contributes $40 \%$ of fodder requirements of animals estimated at 1.5 million heads of which $65 \%$ are goats [20].

2. Ecological role: The geographical latitude of the Argan grove theoretically corresponds to a desert climate [2]. The Argan tree is maintained not only because of its hardiness and resistance to aridity but also because of its great genetic variability [4]. Thus, the Argan woodland is a living barrier against the progress of the desert. The ecosystem protects the soil from wind erosion and runoff and promotes water supply to groundwater, especially in the Souss-Massa plain [15].

3. Social role: It was estimated that the Argan ecosystem contributed between 25 and $45 \%$ to the income of rural families, ranging from 9,000 to 15,000 MAD/year/household depending on the location. The organization of the population through the creation of women's cooperatives was initiated for the promotion of Argan products, especially Argan oil [21]. By 2018, 87 women's cooperatives with nearly 1,500 members produce more than 100,000 litres of oil per year [19]. However, these cooperatives face strong competition from the private sector for the acquisition of the raw material. Several investors are operating in high value-added cosmetic Argan oil [21].

\section{Climate data analysis}

Morocco is a country with a Mediterranean climate where rainfall occurs during the period from September to April (cool season). The hottest months receive little or no rain at all and when it occurs it is in the form of violent storms that bring damage to land, crops and houses [22]. As stated earlier the demand for water exceeds the supply. The difference is compensated by groundwater pumping [15]. Average annual rainfall, which fluctuates roughly between 200 and $400 \mathrm{~mm} /$ year, becomes much lower as one moves towards the Sahara [22]. The number of rainy days also varies widely. It ranges from 20 to 40 days per year on average but can reach 50 days/year on the northern edge of the Argan distribution zone [22]. Snow is a very exceptional phenomenon in the Argan woodland and it is precisely the level of its lowest occurrence that establishes the altitudinal limit of the tree [22]. In order to analyze the variations of climate data over time, four cities representing 4 distinct locations are studied in terms of rainfall and temperature recorded between 1960 and 2020. The locations are the city of Agadir occupying a rather central position in the ABR, Tiznit in the south, Essaouira in the north and Taroudant representing the eastern part with more continental assets (Fig.1). Climate data for these 4 towns were obtained from Terra Climate website (https://app.climateengine.org/climateEngine).

\subsection{Rainfall}

The Souss-Massa plain is characterized by an arid climate with rainfall rarely exceeding $250 \mathrm{~mm} /$ year on average whereas average maximal evapotranspiration is close to 2,000 $\mathrm{mm} /$ year [23]. In the semi-arid area that stretches along the Atlantic coast from Safi to Agadir [22], average annual precipitations range from 250 to $400 \mathrm{~mm}$. The arid area that includes the plains of Souss and Massa and the Anti-Atlas [16], has average annual 
precipitation ranging from 150 to $250 \mathrm{~mm}$. In the southern limit of the Argan woodland, rainfall decreases to less than $100 \mathrm{~mm}$ /year which makes the junction with the Saharan climate [23].

The dry season is very long and can extend to more than 8 months [22]. In general rainfall is very variable: precipitations of a humid year can sometimes be 3 times higher than the average and 15 times higher than the driest year [22]. Average annual rainfall for each location calculated over a period of 60 years is shown in Table 2.

Table 2. Average annual rainfall in Agadir, Essaouira, Taroudant and Tiznit between 1960 and 2020

\begin{tabular}{ccccc}
\hline City & Agadir & Essaouira & Taroudant & Tiznit \\
\hline Average annual rainfall $(\mathrm{mm})$ & $199.4 \pm 25.1$ & $275.8 \pm 29.6$ & $240.3 \pm 41.6$ & $151.9 \pm 22.4$ \\
\hline \multicolumn{4}{c}{ Data from https://app.climateengine.org/climateEngine }
\end{tabular}

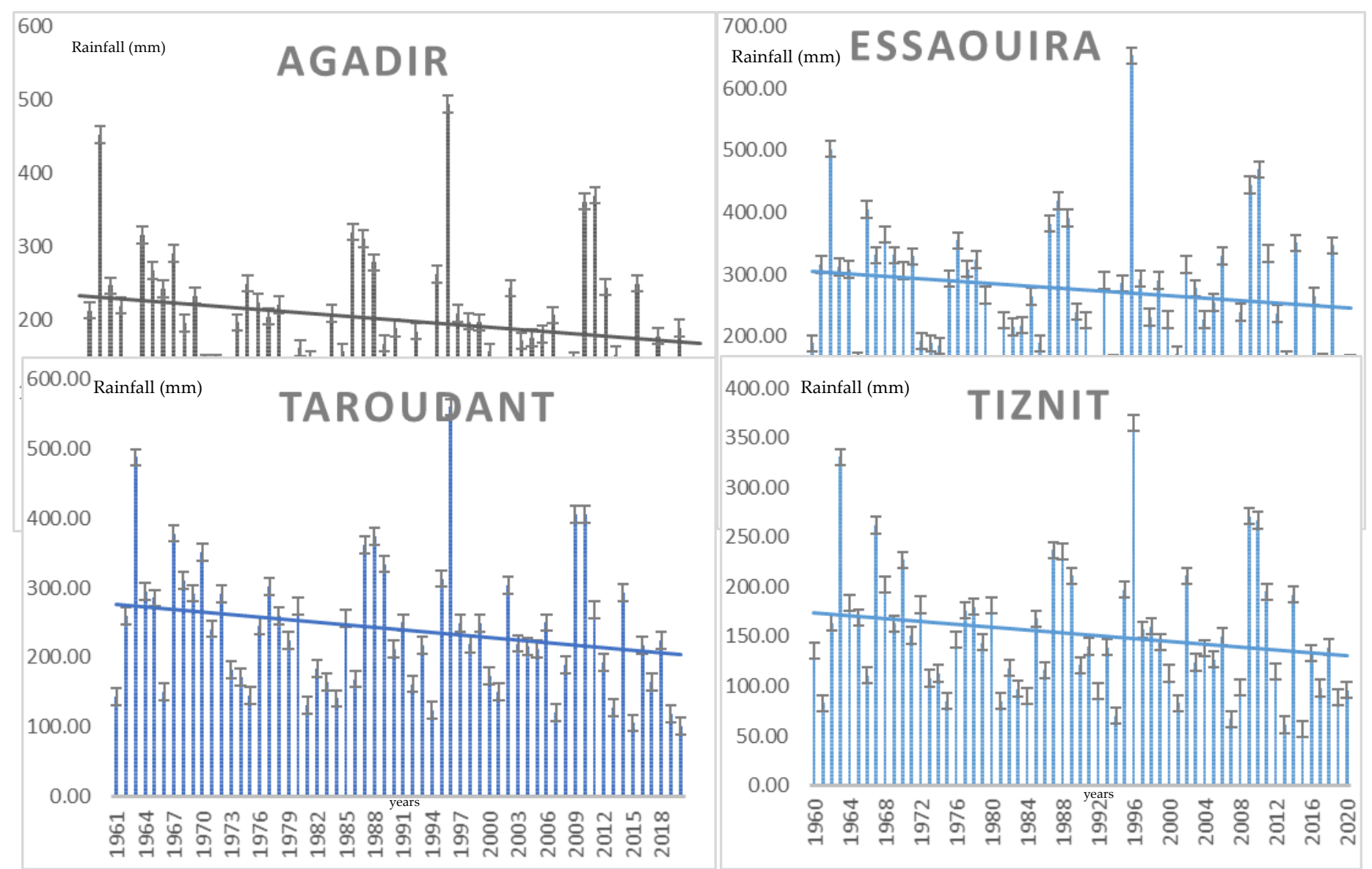

Figure 2. Regression curves for rainfall trend between 1960 and 2020 in mm/year (Agadir; Essaouira; Taroudant and Tiznit). Data from https://app.climateengine.org/climateEngine

For Agadir the regression curve shows a 20.9\% decrease in rainfall between 1960 and 2020 which means that the annual average of precipitations has decreased by one fifth in just 60 years. The same thing happened to Essaouira that lost $18.2 \%$ of its average rainfall over the same period. Rainfall regression curves for Taroudant and Tiznit also show decreases of $26.4 \%$ and $22.2 \%$ respectively.

5.2. Temperature 
Regarding temperature available data between 1960 and 2020 show that the annual average for the 4 locations is $19.4^{\circ} \mathrm{C}$. The average minimum temperatures recorded in January ranged from 10 to $15^{\circ} \mathrm{C}$. The average maximum temperatures for the warmest month (August) ranged from 25 to $34^{\circ} \mathrm{C}$. In summer, the Argan tree can withstand very high temperatures that can reach $50^{\circ} \mathrm{C}$ in the most continental regions [17].
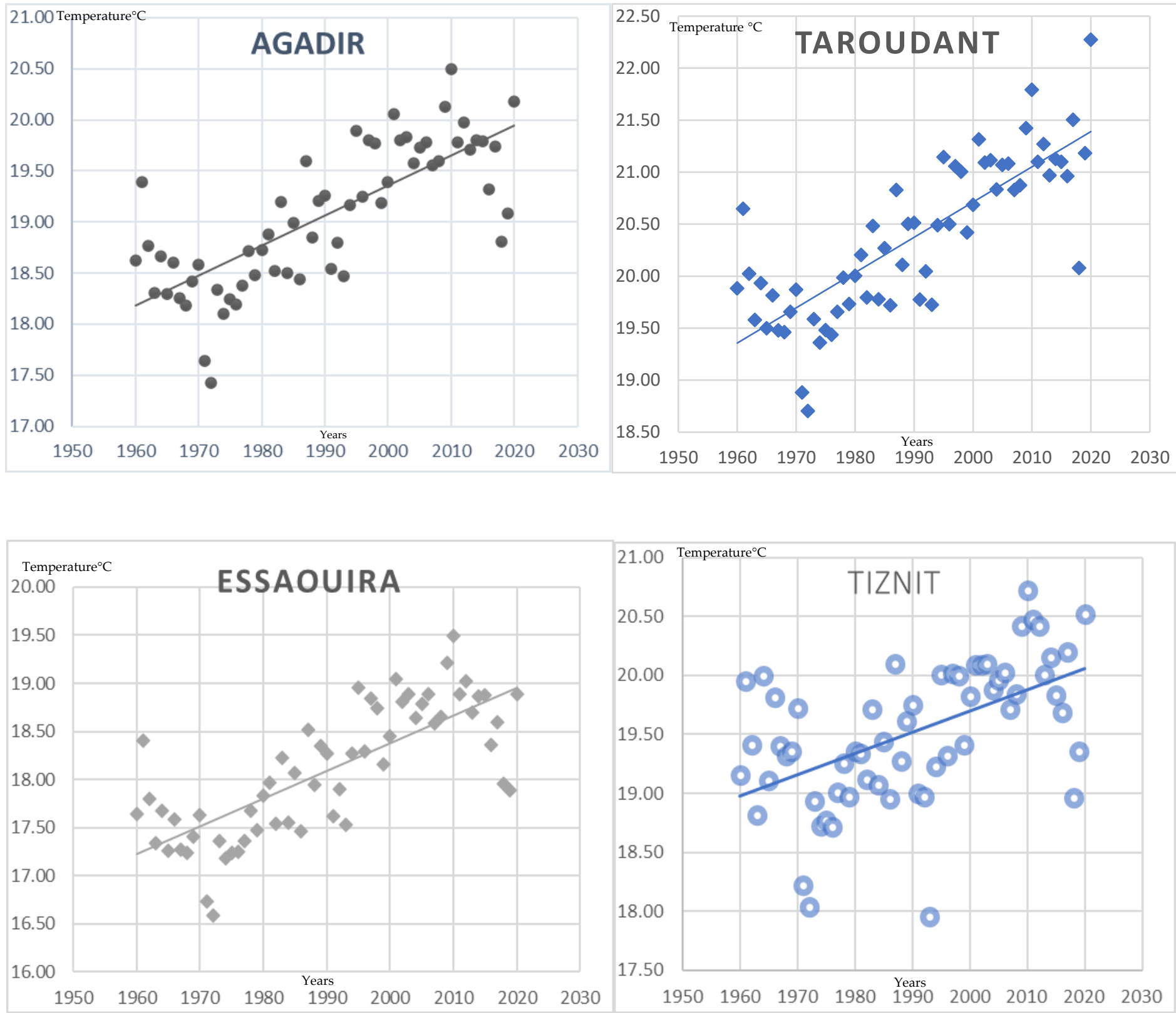

Figure 3. Regression curves for the trend of mean annual temperature between 1960 and 2020 in ${ }^{\circ} \mathrm{C}$ (Agadir; Essouira;

Taroudant; Tiznit). Data from https://app.climateengine.org/climateEngine

The regression trend line illustrates a substantial increase in mean temperatures in the four locations over the last 60 years. Average temperatures in Taroudant, Essaouira, Agadir and Tiznit have increased by $1.98,1.72,1.7$ and $1.06{ }^{\circ} \mathrm{C}$ respectively. This increase is relatively important due to its effect on plant evapotranspiration and hence a greater demand for water.

\section{Soils and geomorphology}


The Argan area is constituted of varied soils due to several physical factors (relief, climate and water balance). These variations allow for different vocations [23]. Good quality soils are mainly distributed on the left bank of the Souss River and in Chtouka plain. The most fertile are located between Agadir and Taroudant, along the northern foothills of the AntiAtlas [23]. Land upstream tributaries of the Souss River derived from the High Atlas is also good and is suitable for all kinds of crops including fruit trees and vegetables [23]. Rather moderately good soils are located between the tributaries of the left bank and around Biougra, as well as the right bank of the Massa River [23]. Less fertile soils cover vast areas in the Tiznit plain and along the coastal strip between Agadir and Tiznit. They are also found along the north-western slopes of the Anti-Atlas overlooking Chtouka, Massa and Tiznit plains [23]. These soils are fragile and must be conserved through rigorous conservation practices.

The main geological features belong to the Secondary and Tertiary eras and are dominated by limestone, dolomites and marl limestone especially in the High Atlas with various outcrops of older ages [23]. However, the upper layers forming the plains are rather of Quaternary age. The conical configuration resulting from the connexion between the High and the Anti-Atlas Mountains with the synclinal widely open on the Atlantic coast offers conditions for the interception of moisture from atmospheric disturbances. As a result, the Souss plain benefits from high levels of air humidity [24].

\section{Challenges and perspectives of the Argan Biosphere Reserve}

\subsection{Challenges facing the Argan Biosphere Reserve}

The combination of economic dynamics, urban expansion and climate change have detrimental consequences on the Argan biosphere reserve. Two kinds of disruptive factors can be identified: (i) direct factors related to clearing actions and (ii) factors that accentuate the decline in vegetation cover [4]. The Souss plain that can be considered as a regulator of water supply is overexploited by excessive pumping that threatens its strategic functions [15]. The Souss aquifer is not only declining but is also salinized by seawater intrusion [15]. Crop producing farms are under serious threat and the three million inhabitants of the area are facing shortages in drinking water [17]. Governmental authorities are aware of this critical situation as they have built a desalination facility to supply water both for drinking and irrigation. The plant will eventually supply irrigation water for 15.000 ha [24]. Over pumping of the alluvial aquifer exceeds an average of $284 \mathrm{Mm}^{3} /$ year in the Souss aquifer and $58 \mathrm{Mm}^{3} /$ year in the Chtouka aquifer resulting in water-level declines ranging from 0.5 to $2.5 \mathrm{~m} /$ year during the past three decades [24]. According to SMHBA report cited by [24], the piezometric level analysis in the Souss aquifers between 1968 and 2003 showed water table decline ranging from $15 \mathrm{~m}$ to more than $70 \mathrm{~m}$ in the Souss upstream and midstream respectively [24]. In the Chtouka aquifer the piezometric level was reduced by over $20 \mathrm{~m}$ [24].

Due to rugged topography, varied rocks, arid climate, proximity to the desert, strong winds and heavy storms, erosion is exposing the Argan woodland to desertification [25]. Demographic and agricultural transformations are making the situation worse by diminishing natural resources such as natural vegetation and water [26]. Certain watersheds are 
affected by spectacular forms of erosion occurring in Badlands and widespread ravines [26]. Wind erosion is very active in the region due to long periods of drought, vegetation cover degradation and water scarcity [26]. It threatens not only areas bordering the coast but also the inland plains of Souss, Massa and Tiznit [25].

The cumulative effects of all these factors ultimately lead to a situation with serious consequences as summarized in the following points.

- Water stress: the intensification of agriculture in the region has led to uncontrolled exploitation of groundwater. The water deficit of the region is $350 \mathrm{Mm}^{3} / y e a r$ with a noticeable decline of the water table level [15].

- Water and wind erosion: land degradation in the region was estimated at 500 tonnes $/ \mathrm{km}^{2} /$ year [25]. This degradation is worrisome as soil reconstruction is slow in arid environments. The area at high risk of erosion accounts for almost $45 \%$ of the total Argan Biosphere Reserve, i.e. 1.12 million hectares approximately [18].

- The regression of Argan cover: in terms of density, it has decreased by two-thirds in 50 years, on average the stands of Argan trees initially composed of 100 stumps/ha have decreased to 30 [27]. In terms of area, the Argan woodland decreased from more than 900,000 ha in 1987 to less than 840,000 ha in 2014, a loss of about 7\% [26].

- Impact of tourism: the intensification of tourism infrastructure (mainly hotels) inside the ABR may lead to the decrease of vegetation cover and environment pollution [28].

\subsection{Perspectives for the Argan Biosphere Reserve}

The Argan Biosphere Reserve has a rich natural and socio-cultural tourism potential attracting eco, cultural and solidarity tourism [28]. UNESCO's recognition of the Argan territory as a biosphere reserve in 1998 is normally valid for 10 years. In 2008 and 2018 the recognition was renewed following evaluation reports [18].

The sustainable development strategy outlined by the Souss-Massa regional council, the dynamism of the economic and social actors, the spirit of entrepreneurship and solidarity that characterize the population of the Argan territory augur the reversal of the trend of desertification and the gradual rehabilitation of this barrier against desert progression.

Since the 1980s, the Argan woodland (plain of Souss) with great agricultural potential (i.e., irrigated and intensive crops for export) have attracted most of the flow of immigration from neighbouring regions, private investment and urban development [21, 26]. Several authors insisted that there is a significant dynamic of deforestation [28]. Between 1989 and 2006, the decline in forest cover for the Greater Agadir alone was estimated at 2.6\% [26]. Rural tourism has the potential to be a source of economic, social and cultural richness for the $\mathrm{ABR}$ in accordance with the principles of sustainable development [28]. Restoring the cultural heritage in the ABR seems to be a key issue for ensuring an ecological and cultural sustainable tourism [29]. Sustainable rural tourism in the Argan territory will ultimately be an effective means of combating poverty in rural areas as well as a means of preserving natural and cultural heritage [29]. It also allows responding to current tourism trends by diversifying the destination of Agadir which suffers from the obsolescence of its tourist product [29]. 
Sustainable rural tourism is the guarantee of human development based on the respect of diversity, territories specificities and on concerted approaches with local communities. As a result, they could control tourism development and take ownership of the benefits of heritage development as well as the economic and symbolic benefits inherent [29].. In this respect, rural tourism would be an effective tool for socio-economic development and can result from integrated and participatory governance [28].

However, it is essential to carry out several urgent actions in this territory including: the collection of rubbish to avoid fly tipping, the fight against anarchic urbanization, the rehabilitation of historical sites, the establishment of tourist signage, the protection and enhancement of the natural and socio-cultural heritage of the Argan ecosystem [30].

A key condition for meeting the water challenge is reducing water deficit that reached 284 $\mathrm{Mm}^{3} /$ year in the Souss valley and $58 \mathrm{Mm}^{3}$ in the Massa perimeter [24]. In terms of sustainable water management, the key challenge clearly is to overcome water scarcity-related problems facing the whole basin of Souss-Massa. This means creating a sustainable water supply system that meets current and future domestic and agricultural water demands and at the same time preserves the water resources for future generations and for the environment [30]. So far governmental authorities have decided that the solution is seawater desalinization. This decision was made with the aim of safeguarding the region's employment potential. Nevertheless, the question of its sustainability should be addressed by specialists.

\section{Conclusions}

The Argan Biosphere Reserve is a vast region of south-western Morocco that covers approximately 2.5 million hectares where nearly 1.3 million rural people live [3]. The Argan forest is the product of a long history between people and the environment: pastoralism, staple food farming, and traditional distribution of access and usage rights [18]. The plots and trees they carry are the result of cultural and economic expression developed through several generations of human beings. The intergenerational link gives the Argan

Biosphere Reserve an undeniable heritage dimension for families and lineages thriving there [5]. Faced with recurrent droughts and the defection of sheep keepers, some authors have reported the decline in the number of goat herds as a general trend in many regions [20].

The decline of one third of the Argan woodland since the beginning of the $20^{\text {th }}$ century is frequently cited [6]. But the main reason for this decline is the expansion of urbanization and intensive agriculture (mainly for export) in the Souss basin [4]. In less urbanized areas negative population growth rates were observed for several decades. Rural exodus and traditional farming decline are normal trends in these arid regions [30]. The natural regeneration of the Argan tree progresses in a spectacular way on the old terraces of cultivation. These observations lead to make a spotlight on the link between rural pressure, global warming and the regression of the tree cover in recent decades [31].

In fact, the landscape of the Souss valley has changed and its natural capital has consequently been degraded [32]. Fifty percent of Argan woodland have been removed, 50\% of underground water stock have been depleted and the Souss river has been modified [24]. 
Methods to help restore this natural capital will impact positively on future catchment management. Urbanization has also induced intensive human consumption patterns beyond the ability of the Argan ecosystem to regenerate its resources [30].

In order to apply the sustainable principles to the Argan Biosphere Reserve Management Plan, three major solutions should be undertaken [30]:

- Mainstreaming natural capital into development policies;

- Rehabilitating the Argan ecosystems;

- Adopting good governance that shall protect and promote inhabitants' rights.

More specifically, a study on watershed susceptibility to erosion, decreasing of their storing capacity, the life of the dams and the consequent corrective actions are crucial to the effectiveness of corrective measures of the watershed management plan [15].

Replication of projects based on sustainable natural resources management and agricultural practices will strengthen the protection of the area's natural resources through reduction of soil loss and protection of natural resources, and will also provide sustainable income to the local population [33]. Responsibility for land management and use is a sensitive issue, involving property rights, and the planting of forest trees remains a controversial issue between the community and government officers (foresters) requiring delicate negotiation and mediation [30].

Switching towards ecological practices in agriculture by utilizing and enhancing the contribution of ecosystem services to farmland coupled with water saving technologies seems to be an appropriate solution for a responsible investment in this vital sector [30]. Sustainable tourism is a responsible approach to minimize environmental damage and combat the overexploitation of a territory's natural resources [29]. The protection and enhancement of the ABRs intangible heritage requires the consideration of measures for its development in the tourism context with the aim of making it an attractive local product symbolizing the development of sustainable tourism [29].

In conclusion, it can be noted that although the Argan tree is a species resistant to drought and lack of water since it digs to enormous depths to look for water, it is now very likely that its roots are no longer adapted to the changes that affect the region; these changes observed over the last 60 years: the increase of 1 to 2 degrees Celsius in temperatures (set as well as a target in order to save the planet for the next 30 years according to [34]) and the decrease of $20 \%$ of precipitation on average, make this endemic resource subject to flagrant pressures embodied by the scarcity of water, water table level reduction, overheating (forest fires), overgrazing, fruit exploitation for its beneficial oils and other factors that limit spontaneous regeneration.

Since the 1960s, the RBA has experienced an accelerated rate of decline previously due to human activities since the early 20th century and accentuated by the aforementioned climate changes. This natural forest, affected by these changes, is now confronted with a strong urban expansion and population growth that disturbs the whole of its natural environment above and below the ground; the water table is consumed as never before and 
its level is declining more and more. Surface water resources, which have become very scarce, suffer from pollution accentuated by tourism and downstream industrial activities. The lack of rainfall and its dispersal are harming both the inhabitants of the region and the stumps of Argan trees that constitute the last barrier against desertification. In addition, the erosion that threatens ABR, aggravated by the succession of dry years and the regression of vegetation cover, is very problematic since it concerns more than $40 \%$ of the studied area.

\section{Patents}

Data Availability Statement: Climate data were found in the following free use website https://app.climateengine.org/climateEngine.

Conflicts of Interest: There is no conflict of interest.

\section{References}

1. M’hirit O., Benzyane M., Benchekroun F., EL Yousfi M. and Bendaanoun M. (1998). The Argan tree: A multi-purpose fruit-forest species, 1 vol. (150 p.): ill., 1 carte; 22- ISBN 2-87009-684-4: 97 FF; (p. 150). Mardaga, Belgique.

2. Romagny B. \& Boujrouf S. (2010). La ruée vers l'huile d'Argan, chronique de la patrimonialisation d'un terroir Marocain. Hespéris Tamuda, 45, 2010, pp. 151-166.

3. Genin D. \& Simenel R. (2011). Endogenous berber forest management and the functional shaping of rural forests in Southern Morocco: Implications for shared forest management options. Springer Science Business Media, LLC 2011 - Doi 10.1007/S10745-011-93.

4. Sinsin T., Mounir F., Qarro M. and Sabir M. (2017). Analyse de la vulnerabilité de l'arganeraie face aux facteurs de désertification au sud du Maroc. Actes de 4 e congres de l'arganier.

5. Hafidi B. . (2007). Dynamique socio-économique dans la Réserve de Biosphère Arganeraie (RBA). Colloque International $\bullet 27-28$ Avril $2007 \bullet$ Rabat.

6. Auclair L. \& Michon G. (2009). La forêt rurale méditerranéenne entre deux paradigms étude comparée des constructions patrimoniales de l'arganeraie marocaine et de la châtaigneraie Corse. Revue Forets Mediterraniennes 2009.

7. Peltier J. P. (1982). La végétation du bassin versant de l'oued Sous (Maroc). Phd Thesis, University of Science, Grenoble, p. 201.

8. Qarro M., Sabir M., Ponette Q., Bejbouij J. and Mormont M. (2013). Facteurs de changement des systèmes arganiers de montagnes. Congres international d'arganier - resume de communication.

9. AFD . (2012). Gestion de la demande en eau dans le bassin mediterraneen - Cas d'étude du Souss Massa. Agence francaise de developpement.

10. Baroud A. \& El Arabi A. (1996). Water resources and hydro-agricultural equipment in the Souss Massa area. Centre International de Hautes Etudes Agronomiques Méditerranéennes 2012.

11. Elame F. , Doukkali M. R. , Fadlaoui A. (2013). Gestion intégrée de l'eau à l'échelle du bassin de SoussMassa: Développement d'un modèle intégré de bassin. Al Awamia 127 - 2013.

12. Irifi H. et al. (2017). Dynamique du paysage forestier de l'arganeraie caractéristiques, évolution et valorisation: Cas de l'arganeraie de la forêt d'ain Tamaloukt, commune territoriale de Tamri, Maroc . Actes Du 4ème Congrès International De L'arganier. 
13. El Mahdad E., Ouhajou L., Bouchaou L., Tazi Sadeq H. (2005). Politique de gestion des ressources en eau et équité hydraulique: Cas des bassins du Souss et du Draa (Sud Marocain). Eaux, pauvreté et crises sociales - politique de gestion des ressources en eau et équité hydraulique - IRD éditions, pp. 599-614.

14. Choukr-Allah R., Nghira A., Hirich A., and Bouchaou L. . (2016). Water resources master plan for sustainable development of the Souss-Massa river basin, Morocco. Hdb Env Chem, Doi 10.1007/698_2016_67, (C) Springer International Publishing Switzerland.

15. Benaddi A. et al. (2017). Les changements territoriaux dans l'arganeraie et leur impact sur la dynamique des peuplements forestiers: Cas de la forêt de Mesguina. Actes Du 4ème Congrès International De L'arganier 2017.

16. El Wahidi F. . (2013). Dynamiques des dégradations de l'arganeraie et modélisation spatiale de l'évolution forestière: Scénarios d'aménagement pour une gouvernance locale. PhD Thesis, Université Catholique De Louvain Earth and Life Institute Http://Hdl.Handle.Net/

17. Chamich M. . (2013). Argan forest: What management for which resource? . Rev. For. Fr. Lxv - 4-2013 - (C) Agroparistech.

18. Bouzemouri B. . (2007). Problématique de la conservation et du développement de l'arganeraie. Colloque International $\bullet 27-28$ Avril $2007 \bullet$ Rabat.

19. Convention on biological diversity report. (2006). Centre d'Echange d'Information sur la Biodiversité du MAROC. http://ma.chm-cbd.net/

20. Bourbouze A. \& El Aïch A. (2005). Goat farming in the Argan grove: The conflicting use of a space. Cahiers Agricultures vol. 14, $n^{\circ}$ 5, septembre-octobre 2005.

21. Bouchelkha M. (2005). L'espace rural dans le Souss: Héritages et changements. Revue Géographique des Pays Méditerranéens Journal of Mediterranean Geography Https://Doi.Org/10.4000/Mediterranee.377, pp. 104105.

22. Alados C.L. \& El Aich A. (2007). Stress assessment of Argan (Argania Spinosa (L.) Skeels) in response to land uses across an aridity gradient: translational asymmetry and branch fractal dimension. Journal of Arid Environments, 01 Apr 2008, 72(4):338-349.

23. Aouragh M. (2012). Dynamique du « paysage-arganeraie » dans le sud-ouest Marocain. Apport des données de télédétection et perspectives de les intégrer dans un SIG. Université Paris Sorbonne-Paris Iv Ecole Doctorale De Géographie De Paris U.F.R. De Géographie Et D'aménagement Umr 8185 Espaces Nature Et Culture (CNRS).

24. Boujnikh M. \& Humbert A. (2010). L'eau dans le bassin du Souss: Concurrences et désorganisation des systèmes paysans. Norois Environnement, Aménagement, Société 214-2010/1 Http://Journals.Openedition.Org/Norois/3178

25. Naggar M. (2018). La gestion durable de l'arganeraie et les enjeux de lutte contre la désertification. Revue Espace Geographique Et Societe Marocaine N22-2018.

26. Ben Attou M. \& Jelloul A. (2017). Les Mutations récentes d'un espace rural dans une zone urbaine de métropolité émergente (Grand-Agadir et le Souss): Cas de l'agriculture périurbaine. Revue Espace Geographique Et Societe Marocaine N18-2017.

27. Zugmeyer L. (2006). Projet de developpement sylvo pastoral de l'arganeraie marocaine. Nancy, france: Ecole Nationale du genie rural, des eaux et des forets.

28. Harif R., Laurent F., Djellouli Y. (2009). L'écotourisme dans Le Parc National de Souss Massa - Maroc. Hal Id: Halshs-00341453 Https://Halshs.Archives-Ouvertes.Fr/Halshs-00341453v3. 
29. Aboutayeb H. (2014). La Réserve de Biosphère de L'arganeraie: Un nouvel éco-territoire touristique au sud du Maroc. Revista de turismo y patrimonio cultural - Vol. 12 N.o 4. P. 915-922. 2014 Https://Doi.Org/10.25145/J.Pasos.2014.12.066.

30. El Fasskaoui B. (2009). Fonctions, défis et enjeux de la gestion et du développement durables dans la Réserve de Biosphère de l'arganeraie (Maroc). Espaces Et Aires Protégés: Gestion Intégrée Et Gouvernance Participative Https://Doi.Org/10.4000/Etudescaribiennes.3711

31. Faouzi H. (2016). Pâturage et dynamique des écosystèmes arganeraies. L'élevage caprin face à la mondialisation. Études caribéennes https://journals.openedition.org/etudescaribeennes/10342

32. FERRADOUS A., BANI-AAMEUR F. and DUPUIS P. (1996). Stational climate, phenology and fruiting of the Argan tree (Argania Spinosa L. Skeels). Actes Inst. Agron. Veto (Maroc) 1996, Vol. 17 (1): 51-60.

33. Msanda F., Mayad E. and Furze J. N. . (2020). Floristic biodiversity, biogeographical significance, and importance of Morocco's Arganeraie Biosphere Reserve. Environ Sci Pollut Res (2021).

34. Meinshausen M. , Meinshausen N. , Hare W. , Raper S.C.B. , Frieler K. , Knutti R. , Frame D.J. and Allen M.R. (2009). Greenhouse-gas emission targets for limiting global warming to 2C. NATURE LETTERS, Vol 458 | doi:10.1038/nature08017. 